International Journal of Business and Management Review

Vol.8, No.4, pp.39-57, July 2020

Published by ECRTD-UK

Print ISSN: 2052-6393(Print), Online ISSN: 2052-6407(Online)

\title{
THE ROLE OF MICRO INSURANCE ON POVERTY REDUCTION: A STUDY OF INSURANCE COMPANIES IN GHANA
}

\author{
Antoinette Yaa Benewaa Gabrah \\ Lecturer, University of Education, Winneba-Kumasi Campus \\ Elijah Takyi Mensah \\ Ph.D. student, Zhejiang Normal University \\ Daniel Yidana \\ Senior Audit Assistant, PKF Ghana
}

\begin{abstract}
Purpose- The purpose of this paper to investigate, explore and assess the role of Micro-insurance in poverty reduction Design/methodology/approach-This paper is a qualitative analysis based on three case studies. Non-probability sampling techniques are used for choosing the unit of analysis which resulted in 4 firms (4 managers). Also, data were collected via a questionnaire and an in-depth interview. Findings- The study identified that Micro-insurance provides financial support to the poor in the event of a disaster, social protection against disasters and shocks, savings, employment, and as well as enhances asset accumulation among clients. The study found that the lack of innovative micro-insurance product, inadequate distribution channels, the lack of supportive micro-insurance legal framework, uncompetitive pricing of micro-insurance products, low government support in micro-insurance programs, low-income levels of respondents, the religious or cultural factors influence the demand of insurance products and low public trust are the factors that affect the demand of micro-insurance products. Also, the study found that the development of innovative products, establishing processes that build trust in clients, instituting efficient service delivery channels, documentation should be simplified and the government should support micro-insurance products are the ways to increase patronage of micro-insurance products. Research limitations- the sample size is still limited and in the future, a quantitative analysis should be used. The study is limited in terms of geographical area. The findings of the study are more likely to hold for another Sub-Saharan context. However, the applicability of these findings to other contexts needs further investigation. Originality/valuewhile interest in micro-insurance is increasing in emerging markets, there is little known and written on micro-insurance. Therefore, the role of micro-insurance has not been explored so far.
\end{abstract}

KEYWORDS: Ghana, insurance, microinsurance, microcredit, poverty alleviation, constraints, insurance, Sub-Saharan Africa

\section{INTRODUCTION}

Africa's economic development and growth ambitions have largely been confronted by a plethora of woes and intractable poverty and social deprivation. In most Third-World Countries, poverty is fast eroding the little economic gains, with a whopping percentage of the populace being poor and unable to get the necessities of life such as portable water, shelter, and electricity. It is estimated 
International Journal of Business and Management Review

Vol.8, No.4, pp.39-57, July 2020

Published by ECRTD-UK

Print ISSN: 2052-6393(Print), Online ISSN: 2052-6407(Online)

that people in Sub-Saharan Africa (SSA) and South Asia are among the poorest in the world (World Bank Report, 2014). To this end, poverty reduction and poverty-focused growth-inducing policies have gained attention in developing economies in recent times amongst governments and multilateral agencies. Poverty itself is a complex, multifaceted phenomenon; its complex nature is replicated in many traits; illiteracy, low economic power, and vulnerability to health problems all of which can be summed up as economic, social and political deprivation of the individual/society (Healey \& Killick, 2000). Poverty makes a person more vulnerable to income, weather shocks, and almost any slight shock in society. Developing countries, such as Ghana face a plethora of challenges concerning the provision of comprehensive social protection. The vast majority of Ghanaians work in the informal economy, so there are no effective mechanisms to reach them through structural reforms. Since they are self-employed or working in informal businesses, there is no formal employer to make contributions to pension, unemployment, or healthcare schemes (Jones, Tafere, \& Woldehanna, 2010). This view has since been backed by (Boateng, Boateng, \& Bampoe, 2015). In spite, the working poor cannot afford the full cost of social security schemes whilst, governments in many developing countries do not have the resources to create sufficient infrastructure (e.g. healthcare facilities) nor pay for the recurring expenses associated with social protection schemes (Yarumba \& Kazungu, 2014).

Many stakeholders have since implemented several policies to curb the menace, one of which policies take the form of insurance. Imagine receiving no support after the loss of property through any natural disaster, it would take years to recoup the losses and be put on a sound path. Insurance, therefore, indemnifies the insured and mitigate any losses in the occurrence of any catastrophe (Werner, 2009). Micro-insurance has over the years been viewed as a new finance discipline. However, micro-insurance is a financial discipline that embodies the concept of microfinance insurance potentially, is one of the basic institutions which can provide a defense mechanism against social and financial exclusion for people whose existing coping strategies are failing (Asmare \& Worku, 2018). And if people's livelihoods are effectively protected, that should encourage investments amongst lower-income groups and raise overall investment and growth rates (Churchill, 2006). Few have access to formal insurance services. Poor people struggle endlessly to ameliorate their lives. It is a slow and gradual process marked by tentative advances. Continually bombarded with financial pressures, low-income households find that shocks can easily erode their hard-earned gains. The efficacy then becomes that their trajectory out of poverty follows a zigzag route: advances reflect times of asset building and income growth; declines are the result of shocks and economic stresses that often push expenditure beyond current income (Churchill, 2006).

The term micro-insurance was first published around 1999, which is yet to receive a definite definition. The definition of micro-insurance is continually evolving. Micro-insurance may be defined as a mechanism that seeks to empower poor people against risk (accident, illness, death in the family, natural disasters, etc.) in exchange for insurance premium payments tailored to their needs, income, and level of risk. According to the International Association of Insurance Supervisors (2007), micro-insurance is defined as insurance that is accessed by the low-income population, provided by a variety of different entities, but run under generally accepted insurance practices. The main aim of this study was to assess the role of microinsurance in poverty reduction 
International Journal of Business and Management Review

Vol.8, No.4, pp.39-57, July 2020

Published by ECRTD-UK

Print ISSN: 2052-6393(Print), Online ISSN: 2052-6407(Online)

using Glico Insurance Ltd. There is evidence that the majority of Ghanaians are still wallowing in abject poverty even though Ghana became a middle-income country in 2010 (Cooke, Hague, \& Mckay, 2016). The 2017 Population and Housing Census report indicated that there was a monumental incidence of poverty in the country using non-monetary measurements than income poverty measurements. From the report, the Greater Accra region was the least poor region in the country (Ghana Statistical Service, 2017).

Development economics researchers showed that micro-insurance as a development instrument has steadily gained popularity over the last decade in low- and middle-income countries (Dror \& Preker, 2002; Armendáriz \& Morduch, 2005; Churchill, 2006). This concept recently arose out of the micro-finance family, where micro-credit and micro-savings have long held the position in terms of most implemented, most developed, and most researched. A common trait of all three concepts is that they generally serve low- to- middle-income people who are not considered under formal financing markets, mechanisms, and products. Many people in low and middle-income countries live in poverty. Depending on the method used, approximately 2.5 billion people live under the international poverty line of $\$ 2$ a day (PPP). Surprisingly, 1.4 billion live under the $\$ 1.25$ a day line (Tumaini et al., 2014). Poverty is mostly concentrated around Asia, Latin America, and especially Africa. Obeng (2011) opined that only 2.6 percent of Africa's population (living under $\$ 2$ per day) has an insurance cover. One dimension of poverty is the market failure of exclusion inaccessibility of the poor to formal financing mechanisms-both credit and insurance, since the poor are often considered too poor to the bank, or insure (Dror, 2006). This has been challenged both academically and empirically by for example professor Yunus of the Grameen Bank, showing that there is a willingness among the poor to use financial services (i.e. loan, save, or pay premiums to be insured) for both investments and consumption smoothening (Armendáriz \& Morduch, 2005; Dror, 2006).

Access to credit is one of the challenges facing Less Developed Countries (LDCs). In Ghana, it is very difficult for those who fall below the poverty line to obtain formal financial services from the mainstream commercial banks as start-up capital and also, to embark on income-generating activities (Cudjoe, 2014). This state of affairs delimits the entrepreneurial spirit of low-income households or earners to contribute their part towards the socio-economic growth of the country. As Helm (2006) puts it over 3 billion people who are living on less than \$2 per day, access to even basic financial services can be a critical ingredient in alleviating poverty. Inadequate access to financial services inhibits poor and low-income people from making routine decisions. Financial services for the poor often referred to as micro-finance, cannot solve all the problems caused by poverty. But they can help put resources and power into the hands of poor and low-income people themselves, letting them make those everyday decisions and chart their paths out of poverty. The innovative and stylistically work of the Grameen Bank Model and its success story in Bangladesh has necessitated worldwide research institutions, academia, NGOs, donor agencies and many development advocates to research into micro-insurance activities and its objective of providing micro-supports systems to the informal sector and thereby reducing poverty (Cudjoe, 2014). It is therefore incumbent on the researcher to find out more about the role of micro-insurance in reducing poverty in Ghana since little literature exists in that area. It is against this background 
International Journal of Business and Management Review

Vol.8, No.4, pp.39-57, July 2020

Published by ECRTD-UK

Print ISSN: 2052-6393(Print), Online ISSN: 2052-6407(Online)

that a study is conducted to assess the role of micro-insurance in poverty reduction in the Glico Insurance Company in the Ashanti region.

The poverty profile in Ghana has generated a plethora of concerns among the populace of the country. The Ghana Living Standards Survey (GLSS-7) in 2016/2017, revealed that more than 2.4 million Ghanaians representing about $12 \%$ of the populace are living in extreme poverty whereas a total of 6.8 million people were considered as poor (Ghana Statistical Service, 2017). The United Nations, in 2002, came out with a Millennium Declaration which aimed at eradicating global poverty. It contained eight development goals which subsequently came to be referred to as the Millennium Development Goals (MDGs). Despite the present and successive government's efforts of fighting the canker, the situation is worsening each day, posing a threat to national security culminating with the rising rate of armed robbery, teenage pregnancy, and conflict among the rural and urban folks. One of such attempts in addressing the issue lately is the emergence of microinsurance. Microinsurance could help with many of these issues by protecting the poor from financial shocks which leaves their income to be invested on their path to economic growth. Microinsurance has therefore been acknowledged to have the potential as an additional risk transfer mechanism to reduce the vulnerability of the poor (Morsink \& Geurts, 2011), Despite the significance of the subject matter, its literature from the Ghanaian perspective remains woefully inadequate, generating the need for a study on the role of microinsurance in poverty alleviation and reduction, using Glico Insurance as the researched institution.

Additionally, other researchers that attempted a study in similar topics in Ghana delved more on microfinance, either than micro-insurance. There have been a few research conducted by scholars like Cudjoe (2014) focused on the role of micro-finance institutions in poverty reduction in the Central Region of Ghana, Arun, and Steiner (2008) stressed on the micro-insurance in the context of social protection and Giesbert (2013) also preferred to investigate on micro-insurance and risk management, evidence from Ghana. It is against this backdrop this study is being investigated to assess the role of Micro-insurance in Poverty Reduction: The case of Glico Insurance Company Limited. Agyapong (2015) lamented the inadequate information quite prevalent in the insurance industry in Ghana. He opined "There is no current information in the industry to help industry players to work and make good policies thereof and address the needs of stakeholders in the industry. Adequate information has a positive correlation with good formulation and implementation of effective policies. Availability and easy access to accurate statistics on the Ghanaian insurance market remains a monumental challenge to the sector currently. As of September (2010), only the 2005 Annual Report on the insurance industry was available at the web site of the National Insurance Commission (NIC). On October 19, 2008, the results of the first-ever Ghana Insurance Award were rejected because the stakeholders disagreed over winners in some categories. The Institute of Social, Statistical and Economic Research (ISSER), who were responsible for the compilation of the results, failed because of what was perceived to be inadequate information and inaccurate statistics about the companies. Unlike other financial institutions such as the banks, it is uncommon to see financial statements of the insurance companies, brokers, reinsurance, and loss adjusters in the public. Financial statements of most insurance companies are found only at their work premises on a request. Most Ghanaians, therefore, are bamboozled about what transpires in the industry. This has affected insurance 
International Journal of Business and Management Review

Vol.8, No.4, pp.39-57, July 2020

Published by ECRTD-UK

Print ISSN: 2052-6393(Print), Online ISSN: 2052-6407(Online)

penetration negatively in Ghana. Insurance penetration in Ghana for 2008 was $1.57 \%$, a very low rate as compared to jurisdictions like South Africa with a rate of $12.7 \%$ (National Insurance Commission [NIC] Annual Report, 2008). Research of this caliber is, therefore, needed to add adequate information to the industry since the insurance industry strives on vital adequate information.

\section{LITERATURE REVIEW}

\section{Micro-insurance}

Micro-insurance programs have expanded rapidly in many developing countries over the past 20 years and are now widely regarded as an integral part of the social protection system (Sirojudin \& Midgley, 2012). The concept of micro-insurance is a more complex concept than micro-credit (De Bock \& Gelade, 2012). This shows that micro-insurance as a concept is crucial in current times. Micro-insurance embodies the safeguarding the low-income people against specific perils in exchange for regular premium payments proportionate to the likelihood and cost of the risk envisaged (Churchill, 2006). The fundamental underlying principle pooling of risks operates based on the fact that financial contributions are collected from the members of an insurance scheme, and the loss of one individual is spread among all members in case of risk occurrence. The distinctive line between micro-insurance and regular insurance is that the former is specifically targeted at low-income people, who have limited financial resources and often-irregular income flows. Thus, the product design is tailored to meet the needs of these people and financial capabilities. With microinsurance, low-income people can hedge risk. Hedging entails minimizing or controlling risk and it is done by taking a position in the futures market that is opposite to the one in the physical market to limit risks associated with price changes (Chakrabarty, 2007). Hedging is a two-step process where a gain or loss in the cash position due to variation in price levels will be countered by changes in the value of a futures position (ibid). For instance, a cocoa farmer can sell cocoa futures to protect the value of his crop before harvest. If there is a fall in price, the loss in the cash market position will be countered by again in a futures position. Conceptually, micro-insurance is a function of income and no-income poverty, which manipulates uninsured risks such as unemployment, illness, disability, deaths, crop failure, crime, and natural calamities. The uninsured risks leave poor households vulnerable to serious and catastrophic losses from negative shocks. Welfare costs due to shocks and foregone profitable opportunities are substantial, contributing to persistent poverty. Microinsurance has the potential to reduce these welfare costs by offering a payout when an insured loss occurs (Tumaini \& Kazungu, 2014).

Insurance plays a significant role in the functioning of modern economies given the fact that insurance penetration levels accounted for 4.8 percent of the gross domestic product (GDP) of India in 2011 and further grew to 6 percent in 2012 (Barik, 2012). However, the same cannot be said from the Ghanaian perspective as only five percent of the Ghanaian populace has an insurance package in the form of protection for themselves, their beneficiaries, and possessions (NIC, 2011). The industry's contribution to the country's gross domestic product hovers within 1 percent, as compared to South Africa 14.8 percent, Namibia 7.3 percent, Kenya 2.8 percent, Nigeria 0.6 percent, and Malaysia 4.8 percent (Swiss Re Sigma Report, 2012). 
International Journal of Business and Management Review

Vol.8, No.4, pp.39-57, July 2020

Published by ECRTD-UK

Print ISSN: 2052-6393(Print), Online ISSN: 2052-6407(Online)

\section{Insurance in Ghana}

The archaeology of Ghana's insurance history dates back in the colonial era in (1924), when the then Royal Guardian Enterprise, now known as Enterprise Insurance Company Limited was established. In (1955), Gold Coast Insurance Company was formed as the first indigenous private insurance company followed by State Insurance Company in (1962). By the year (2008), licensed insurance companies within the country had increased to (39), given the breakdown as (17) in the life insurance and (22) for no- life insurance. Insurance companies in Ghana are in three categories namely; Life Insurance, Non-Life Insurance, and Composite Insurance which is the amalgamation of life and non-life insurance, (Boadu, Dwomo-Fokuo, Boakye, \& Frimpong 2014). The major driving agents of the insurance market comprise insurance companies and policyholders (insurers). The insurance market is divided into Life and Non-life insurance. Each market has its supply and demand. The demand side of the Life market is constituted by the policyholder who wants compensation upon death, terminal illness or critical illness, whilst the Non-Life market demand size is formed by the automobile and homeowners' policyholders. The supply side of both markets is populated by insurers who seek to indemnify policyholders. The insurance market has a tremendous effect on the national economy by creating jobs, paying taxes to the government for other developmental activities, and protecting the citizenry from loss of properties among others, (Boadu et al., 2014). The (1989) insurance law, PNDC Law (229), established the National Insurance Commission (NIC), as the body with the mandate of insurance issues in Ghana. It is mandated to ensure effective administration, supervision, regulation, and control activities as enacted in the Insurance Act, 2006 (Act 724), (Boadu et al, 2014). The commission was established essentially to handle the plethora of complaints of customers over the years about the type of services they received from the insurance companies.

Customers are valuable assets for any organization as they are the ultimate destination of any products or services (Thapa, 2015). The success of any organization depends upon the satisfaction of the consumers since they are the end-users of organizational products or services and can decide to stay or switch to other brands based on their satisfaction. The customer is the only source of the company's present profit and future growth (Gray \& Byun, 2001). Due to the high degree of globalization of markets and intense competition among the players in the insurance industry, more attention needs to be paid towards customer satisfaction and retention if the major players do not want to lose their existing customers. The fundamental sustainable competitive advantage in today's competitive business environments lies in delivering high-quality service that results in satisfied customers (Parasuraman, Berry, \& Zeithaml, 1991). Addressing customer needs had become a great differentiator, the most powerful competitive weapon which many leading service organizations possess (Boadu et al, 2014).

Nonetheless, despite the establishment of NIC, Ghanaian insurance companies are often accused of behaving as if they are doing a favor to their customers. The insurance industry suffers most from negative image due to lower customer satisfaction perception (NIC, 2008). The public has different perceptions and misconceptions about insurance policy providers as policy providers are accused of concentrating on only the rich at the neglect of the poor. A researcher once remarked that "most insurance companies came for only the rich". 
International Journal of Business and Management Review

Vol.8, No.4, pp.39-57, July 2020

Published by ECRTD-UK

Print ISSN: 2052-6393(Print), Online ISSN: 2052-6407(Online)

Micro Insurance and Poverty Alleviation

The world is being caught in the poverty web. Poverty continues to be a major setback confronting both advanced and less-advanced nations. The main objective of microinsurance is to reduce poverty and indemnify the less privileged in the event of any natural disaster. In doing this, microinsurance offers the opportunity for clients to create wealth, whilst concurrently being redeemed in case of substantial losses. Targeting the aged, women, and children in the society who constitute the majority of the poor, micro-insurance helps to curtail poverty by creating wealth which leads to an increase in the levels of incomes of the vulnerable through reimbursement during losses. Savings services lead to capital accumulation for investment in the short and long terms. With selected insurance companies A, B, C, and D, clients can be registered for minimum savings up to a given period, and if no loss of property, lives, etc. occur, they take back their savings for other equally important things. With rising incomes, the vulnerable are empowered. They are to cater for themselves and children, make decisions that affect their household, educate their children, and engage in income-generating activities. The extent to which micro-insurance services contribute to the poverty reduction largely depends on access to these services by the poor and destitute. Not only this but also it depends on promising investment opportunities and on the capacity of the poor to tap into these investment opportunities. Especially if in the rural areas investment opportunities are not expanding simultaneously with micro insurance services, not much can be achieved (Morduch, 2006).

In Bangladesh, where about one-third of the world's estimated 30-40 million micro borrowers reside, the growth has come from specialized micro insurance, NGO's and Grameen Bank. What began with a few small grants and loans from international donors has now provided over 100 million dollars in loans. The most distinctive feature of the credit delivery system is the absence of middlemen between the credit supplier and end-user. The bank's cumulative recovery rate is an astounding 98 percent. Grameen Bank has its special legal structure and does not fall under the regulatory oversight of the central bank. The bank also aims to raise health and environmental consciousness. Each of its members must plant at least one sapling a year as part of the forestation program. Grameen is perhaps the only bank in the world that encourages birth control, sanitation, and a clean environment as part of its lending policy (Yunus, 2001). In Bolivia, the microfinance and insurance revolution emerged in the 1990s. Large-scale commercial credit was provided thereby BancoSol, a privately-owned bank for micro-entrepreneurs and by several competitors following hotly on BancoSol's heels and profits). By 1997, BancoSol, financed by a combination of domestic and international commercial debt and investment and locally mobilized voluntary savings, provided loans profitably to more than one-quarter of Bolivia's clients (Morduch, 2006). As reported by the Wall Street Journal (15 July 1997), "the real measure of its success is that BancoSol has spawned a slew of competitions ${ }^{\text {ee }}$.

In India, despite the large size and depth of its financial system, most of the rural poor do not have access to formal finance and financial services. For this reason, innovative microfinance initiatives pioneered by nongovernmental organizations strove to create links between commercial banks, NGOs, and informal local groups to create the SHG Bank Linkage (Development gateway, 2004). India's approach to microinsurance made it profitable and so widely available helped the country reduce the incidence of poverty from about 40 percent of the population in the mid-1970s to about 
International Journal of Business and Management Review

Vol.8, No.4, pp.39-57, July 2020

Published by ECRTD-UK

Print ISSN: 2052-6393(Print), Online ISSN: 2052-6407(Online)

11 percent in 1996 (Morduch, 2006). Members of SHG observed that several challenges lie ahead, but still believe it had the right ingredients to be scaled-up into offering mass access to microinsurance for the rural poor whilst enhancing sustainability ${ }^{e e}$ (World Bank, 2003). The World Development Report for 1990 (World Bank, 1990) found that poverty could be reduced most effectively by a strategy with two equally important elements. The first element is to promote the judicious use of the amplest asset of the poor, labor. Broad-based economic growth through appropriate macroeconomic and microeconomic policies is critical in this respect. There is also an indispensable role for policies targeted at promoting infrastructure development and encouraging income generation activities for the poor. The second element is to provide basic social services to the poor. The World Bank found that primary health care, family planning, nutrition, and primary education were especially important in this regard.

In most developing countries, including Ghana, opportunities for wage employment in the formal sector of the economy are woefully inadequate, and the clear majority of the poor depend on selfemployment for their livelihood. Better access to microinsurance services enables the poor to establish and expand micro-enterprises and thereby ameliorate their income levels and create employment. Even in middle-income countries such as Botswana, Ghana, and Egypt, where opportunities for wage employment are greater, many poor households rely on self-employment in micro-enterprises for their livelihood (Kessey, 2013). Prudent policies drawn up to encourage the development of an effective microfinance sector can also reinforce other poverty reduction agenda and vice versa. Many microinsurance institutions, including Glico Insurance, Enterprise Insurance, and Metropolitan Insurance, urge their clients to develop a socio-economic agenda covering matters such as health, nutrition, and education of children. Even where this emphasis is not explicit, increased empowerment and higher income for clients as a result of their participation in microinsurance products will propel them to adopt other socio-economic agenda. At the same time, micro-insurance institutions are likely to be more effective in raising the incomes of beneficiaries in the case where rapid growth in the economy and agricultural output and better infrastructure creates demand for the products and services provided by micro-entrepreneurs. Microinsurance programs will also be more effective where the provision of non-financial services such as education and training enables clients to use their loans more productively (Boadu et al., 2014).

\section{Poverty Alleviation and Micro Insurance Programs}

Providing the poor with access to financial services is one of many ways to help augment their incomes and productivity. In many countries, however, traditional financial institutions have failed to provide this service (Braverman \& Guasch, 1986). Microcredit and co-operative programs have been developed to fill this gap. Their purpose is to help mitigate risks associated with loss of property among the poor and hence, escape poverty. Many of these programs provide credit using social mechanisms, such as group-based lending, to reach the poor and other clients, including women, who lack access to formal financial institutions (Huppi \& Feder, 1990). With increasing assistance from the World Bank and other donors, micro insurance is emerging as an instrument for reducing poverty and improving the poor's access to financial services in low-income countries (World Bank, 1990). The question now is how can microcredit reduce poverty? The answer is not far-fetched. In the words of Boadu et al. (2014), micro insurance can help to alleviate poverty 
International Journal of Business and Management Review

Vol.8, No.4, pp.39-57, July 2020

Published by ECRTD-UK

Print ISSN: 2052-6393(Print), Online ISSN: 2052-6407(Online)

through indemnity, encouraging savings among low-income earners, and educating clients on the availability of microinsurance products. Odenyo (2013) concluded that micro-insurance plays a crucial role in alleviating poverty. For instance, micro-insurance alleviates the financial burden on the poor in the event of a disaster and it protects the wealth and asset of the poor. Undoubtedly, several other works agree with this finding in that Akotey et al. (2011) in their earlier works found that micro-insurance impacts greatly in alleviating poverty among the poor. In the same vein, Akotey and Adjasi (2014) added that micro-insurance impacts on household asset accumulation in that micro-insurance equips household to cope effectively with risks, empowers them to escape poverty ad it sustains the welfare gains achieved. Akotey and Adjasi (2018) further corroborate this finding. This demonstrates that micro-insurance plays a crucial role in alleviating poverty in countries.

Studies reveal that micro-insurance helps to cope with shocks. For instance, Dietrich (2017) found that micro-insurance payouts to small scale farmers in the case of natural disaster help to mitigate the financial consequences that come with it. Again, Bauchet, Damon, and Larsen (2017) found that micro-insurance provides social protection. This reveals that one of the roles of microinsurance is that it reduces the financial consequents of disaster. Further studies like Churchill (2008) admit that micro-insurance help to protect the poor by providing financial assistance to support the needy. This has forced other authors like Arun and Steiner (2008) and Alderman and Haque (2007) to observe that micro-insurance offers social protection particularly, in emerging countries. Boadu et al. (2014), micro insurance can help to alleviate poverty through indemnity, encouraging savings among low-income earners, and educating clients on the availability of microinsurance products. Again, another study found that Better access to microinsurance services enables the poor to establish and expand micro-enterprises and thereby ameliorate their income levels and create employment (Kessey, 2013). In the same vein, Akotey, Osei, and Gemegah (2011) concluded that there is a link between micro-insurance services and household asset accumulation in Ghana.

\section{Factors Affecting Micro-Insurance Demand}

There have been several works done in the area of micro-insurance demand. For instance, a study that sought to investigate determinants of micro-insurance demand using mean score analysis found that premium flexibility, income level, and nodal agency are significant determinants of micro-insurance demand (Akotey, Osei, \& Gemegah, 2011). Again, they found that expectation (trust) and marital status were also the main determinants of micro-insurance. A similar study by Kamau (2013) in his quest to investigate the factors contributing to insurance penetration found that the nature of the industry, income, cost of insurance, and demographic factors are factors that affect micro-insurance demand in the country. Odenyo (2013) in a similar study concluded that several factors influence the demand for micro-insurance including income, cost of insurance, and low public trust in micro-insurance. Literature suggests that religious and cultural factors affect the demand for micro-insurance (Erlbeck, 2017; Odenyo, 2013). Scholars like Cole (2015) admitted that there is little academic literature on micro-insurance adoption in emerging markets. Another study found that there is an extant knowledge on the determinants of micro-insurance demand in a manner that achieves several outcomes (Eling, Pradhan, \& Schmit, 2014). This shows that there is little known in the area of micro-insurance. Nevertheless, micro-insurance has recently 
received much attention as a promising tool to protect poor individuals from important shocks (Platteau, De Bock, \& Gelade, 2017).

\section{Ways to Increase Micro-Insurance Demand}

Odenyo (2013) suggested that the adoption of micro-insurance can be increased by enhancing product innovation in the insurance industry; there should be efficient service delivery channels; documentation should be simplified and lastly, measures should be instituted to build trust as well as create awareness of the micro-insurance products. Other scholars like Cole (2015) further recommend that particular attention should be paid to micro-insurance for the government in supporting the development of microinsurance in emerging markets. A similar study found that regulation in micro-insurance markets may promote social welfare.

\section{Conceptual Framework}

From Figure 1, the study conceptualizes that several factors influence micro-insurance demand and these factors consist of uncompetitive pricing, micro-insurance products, the distribution channels, micro-insurance legal framework, the income levels of individuals, the level of public trust and the religious or cultural factors. This study assumes that these may influence the demand for micro-insurance negatively. Again, the study assumes that the patronage of micro-insurance will lead to a reduction in poverty levels of individuals who patronize it. Reduction in poverty is measured with financial support, accumulation of wealth, protection on disasters and shocks, savings, and employment. Therefore, the study sought to find answers to these assumptions.

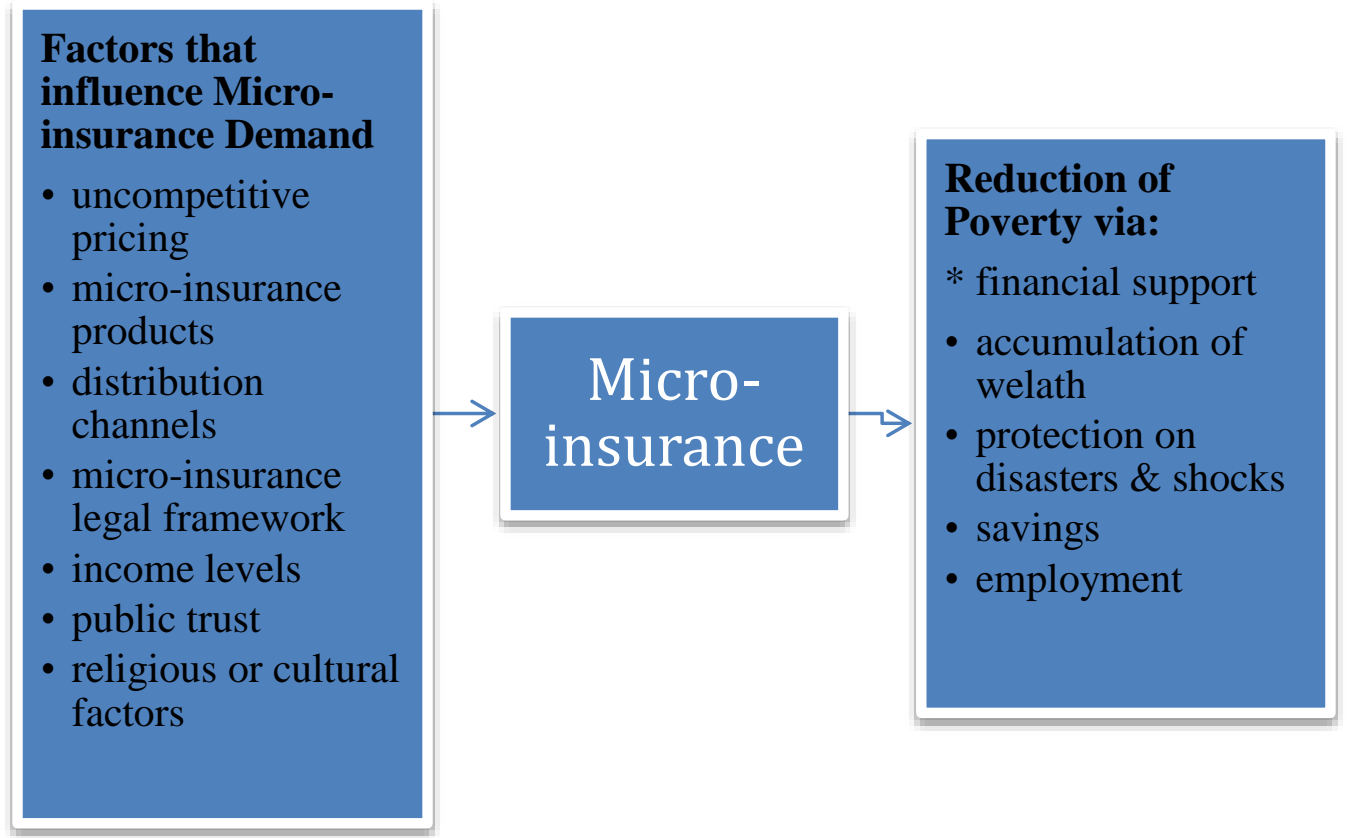

Figure 1: The Conceptual Framework of the Study

Source: Adapted from Kamau (2013)

\section{Summary of Literature Review and Research Gap}

Low-income earners are particularly vulnerable to risk and negative external shocks such as natural disasters; illness/ death of the main breadwinner, due to their low asset bases. In the absence of 
International Journal of Business and Management Review

Vol.8, No.4, pp.39-57, July 2020

Published by ECRTD-UK

Print ISSN: 2052-6393(Print), Online ISSN: 2052-6407(Online)

functioning insurance markets, poor people in developing countries such as ours have created effective strategies expressed in several formal and informal instruments to manage such risks. These include risk-pooling schemes such as funeral and burial societies, income support in the form of credit arrangements, transfers, and consumption smoothing arrangements such as savings and grain banks (Boadu et al., 2014). Nonetheless, such informal and formal approaches offer limited protection, low returns for households, and are prone to breakdown during emergencies. Community-based risk management schemes also depend largely on personal relations between participants, limiting scalability and geographic spread. Even formal support programs such as food-for-work may be exclusionary, as in the case of female-headed households are often left out of such work programs as they face difficulties in making the required labor contribution.

Formal insurance instruments can offer quality risk management options, provided poor households can access these services. Without insurance, low-income households forego greaterreturn livelihood strategies for lower-risk avenues that curtail risk. Insurance products assume such risk thus reducing household efficiency losses and protecting assets so that the poor can escape poverty traps. Insurance instruments pool the risks of individuals of a similar risk class and transfer it to a larger and more diverse group of market participants through the 'hedging' process. Traditional forms of insurance, however, have often been beyond the reach of the poor. Innovations in microinsurance aim at increasing outreach and coverage across lower-income tiers (Satterthwaite \& Bartlett, 2017).

Micro-insurance is indeed a momentous effort, complementing the prevailing menu of social protection programs. A flexible and powerful instrument, micro insurance (MI) reduces vulnerability and mitigates the negative effects of external shocks on low-income earners. However, micro-insurance programs require well-developed institutional arrangements to run efficiently and effectively and wider awareness creation to persuade the overall public of enrolling for their existing products. There is evidence that alludes to the existing literature gap on the subject matter, (Boadu et al. 2014; Tumaini \& Kazungu, 2014), warranting the need for this study to unravel current trends on the role of microinsurance on poverty alleviation, using the selected insurance companies.

\section{Data Collection and Methodology}

The literature on qualitative case design in business research guided the collection and analysis of data (Eisenhardt, 1989; Yin, 2003; 2009). The researcher interviewed 150 customers and 50 employees within a six months field study in Ghana involved 3 key insurance companies. All the interviews were semi-structured, face-to-face, and in English. Both the employees and customers were interviewed, from January 2018 to June 2018. These interviews were conducted at the offices of the selected cases. These respondents have at least seven years of work experience with their respective insurance firms. These interviews lasted for over one and a half hours. The study employed the use of questionnaires as the main data collection instrument. The documentation inspired the researcher for interview questions and provided an opportunity to check on information. The study adopted a descriptive research design as well as descriptive statistics in analyzing the data collected. 
International Journal of Business and Management Review

Vol.8, No.4, pp.39-57, July 2020

Published by ECRTD-UK

Print ISSN: 2052-6393(Print), Online ISSN: 2052-6407(Online)

\section{Case Study Findings}

Role of Micro-insurance in Alleviating Poverty

This section focuses on the role of microinsurance in alleviating poverty and the results are present in Table 2.

Table 2: Contribution of Micro-Insurance in Poverty Alleviation

\begin{tabular}{lll}
\hline & Frequency & Percent \\
\hline Tremendous contribution & 63 & 42.0 \\
Very little contribution & 76 & 51.0 \\
No impact & 11 & 7.0 \\
Total & $\mathbf{1 5 0}$ & $\mathbf{1 0 0 . 0}$ \\
\hline
\end{tabular}

Source: Field Survey (2018)

The study found out in Table 2 that, $51 \%$ of the respondents indicated that microinsurance products had very little contribution to poverty alleviation whilst $42 \%$ indicated that it had tremendous contribution and a little over $7 \%$ showed that microinsurance products had no impact on poverty alleviation. This shows that the majority of the respondents perceive that microinsurance has very little impact on alleviating poverty.

Table 3: The Role of Micro-insurance in alleviating Poverty (Staff)

\begin{tabular}{llll}
\hline Variables & $\mathbf{N}$ & $\mathbf{M}$ & SD \\
\hline $\begin{array}{l}\text { Micro-insurance provides financial } \\
\text { support to the poor in the event of a } \\
\text { disaster }\end{array}$ & 50 & 4.89 & 0.56 \\
$\begin{array}{l}\text { Micro-insurance ensures social } \\
\text { protection against disasters and shocks }\end{array}$ & 50 & 4.51 & 0.53 \\
$\begin{array}{l}\text { Micro-insurance protects the wealth of } \\
\text { the poor }\end{array}$ & 50 & 4.23 & 0.51 \\
Micro-insurance encourages savings & 50 & 4.32 & 0.57 \\
$\begin{array}{l}\text { It provides employment } \\
\text { It ensures asset accumulation }\end{array}$ & 50 & 3.99 & 0.51 \\
Total & 50 & 3.78 & 0.50 \\
\hline
\end{tabular}

Source: Field Survey (2018)

In a bid to examine the role of micro-insurance in alleviating poverty to their clients (both staff and customers), respondents were asked to rate the extent to which they agree to the statements as the role of micro-insurance. From Table 3, the respondents asserted that Micro-insurance provides financial support to the poor in the event of a disaster with a calculated mean of 4.89 and a standard deviation of 0.56 . The respondents further identified that Micro-insurance ensures social protection against disasters and shocks with a calculated mean of 4.51 and a standard deviation of 0.53 . The statement, "micro-insurance encourages saving" accorded an approval ratings $(\mathrm{M}=4.32, \mathrm{SD}=$ 0.57) from the respondents. The statement "micro-insurance protects the wealth of the poor" followed this as it obtained an approval rating of $(\mathrm{M}=4.23, \mathrm{SD}=0.51)$. The respondents further agreed to the statement "micro-insurance provides employment" $(\mathrm{M}=3.89, \mathrm{SD}=1.16)$. Finally, 
International Journal of Business and Management Review

Vol.8, No.4, pp.39-57, July 2020

Published by ECRTD-UK

Print ISSN: 2052-6393(Print), Online ISSN: 2052-6407(Online)

the respondents identified that micro-insurance ensures asset accumulation with a calculate mean of 3.78 and a standard deviation of 0.50 . This reveals that micro-insurance alleviates poverty since Micro-insurance provides financial support to the poor in the event of a disaster; Micro-insurance ensures social protection against disasters and shocks; it encourages savings; it provides employment and finally, it ensures asset accumulation.

Table 4: Role of Micro-insurance in alleviating Poverty (Clients)

\begin{tabular}{llll}
\hline Statement & N & M & SD \\
\hline $\begin{array}{l}\text { Micro-insurance provides financial support to the poor in the event of a } \\
\text { disaster }\end{array}$ & 150 & 4.48 & .71 \\
Micro-insurance ensures social protection against disasters and shocks & 150 & 4.48 & .70 \\
Micro-insurance protects the wealth of the poor & 150 & 4.16 & 1.02 \\
Micro-insurance encourages savings & 150 & 4.00 & .63 \\
It provides employment & 150 & 4.14 & 1.43 \\
It ensures asset accumulation & 150 & 3.48 & .71 \\
\hline
\end{tabular}

Source: Field Survey (2018)

The clients of the firm were also asked to indicate the role micro-insurance plays in alleviating poverty and the responses were: the respondents identified that micro-insurance provides financial support to the poor in the event of a disaster as well as ensures social protection against disasters and shocks with a calculated mean of 4.48 and a standard deviation of 0.71 and this indicates that they agree that micro-finance offers financial support to them when needed. Also, they noted with a calculated mean of 4.16 and a mean of 1.02 that micro-insurance protects the wealth of the poor. This shows that micro-insurance offers them protection for their wealth (See table 4). The clients further identified that micro-insurance encourages savings with a calculated mean of 4.00 and a standard deviation of 0.63 . This assertion shows that micro-insurance promotes savings. They also stated that micro-insurance employs with a calculated mean of 4.14 and a standard deviation of 1.43 , which shows that micro-insurance, certainly offers employment to people. Nonetheless, the clients were uncertain about the fact that micro-insurance promotes asset accumulation.

The study identified that Micro-insurance provides financial support to the poor in the event of a disaster; Micro-insurance ensures social protection against disasters and shocks; it encourages savings; it provides employment and as well as enhancing asset accumulation. This confirms studies such as Bauchet, Damon and Larsen (2017), Boadu et al. (2014), Dietrich (2017), Akotey and Adjasi (2018) and Odenyo (2013) who argued that micro-insurance alleviates poverty via the provision of financial assistance to the poor in the event of a disaster; protecting the asset of the poor against disaster; promoting asset and wealth accumulation and encourages savings. This relates to the social exchange theory in the way that micro-insurance offers improved social welfare benefits to people be it staff or clients of micro-insurance firms. 
International Journal of Business and Management Review

Vol.8, No.4, pp.39-57, July 2020

Published by ECRTD-UK

Print ISSN: 2052-6393(Print), Online ISSN: 2052-6407(Online)

\section{Factors that affect the demand of Micro-insurance}

This section addresses issues about the second objective of the study and the results were presented in Table 4.

Table 5: Factors that affect the demand of Micro-insurance

\begin{tabular}{llll}
\hline Variables & N & M & SD \\
\hline The lack of innovative micro-insurance product & 150 & 4.49 & 0.55 \\
Inadequate distribution channels which limit the reach & 150 & 4.43 & 0.54 \\
$\begin{array}{l}\text { and low levels of publicity } \\
\text { Lack of supportive micro-insurance legal framework }\end{array}$ & 150 & 4.30 & 0.54 \\
Uncompetitive pricing of micro-insurance products & 150 & 4.29 & 0.54 \\
Low government support in micro-insurance programs & 150 & 4.18 & 0.50 \\
Low-income levels of people who relegate insurance to & 150 & 4.14 & 0.49 \\
secondary needs & & & \\
Religious or cultural factors that are hostile towards & 150 & 4.05 & 0.59 \\
insurance & & & \\
Low public trust in micro-insurance companies & 150 & 3.93 & 0.54 \\
Total & $\mathbf{1 5 0}$ & $\mathbf{4 . 2 5}$ & $\mathbf{0 . 1 8}$ \\
\hline
\end{tabular}

Source: Field Survey (2018)

From Table 5, the respondents identified the lack of innovative microinsurance products as one of the factors that influence demand with a mean of 4.49 and a standard deviation of 0.55 . Also, inadequate distribution channels, which limit the reach and low levels of publicity with an estimated, mean of 4.43 and a standard deviation of 0.54 were also identified as a factor that influences the demand of micro-insurance products among respondents. Respondents strongly agree with the assertion that one of the factors that affect the demand for micro-insurance products is the lack of supportive micro-insurance legal framework with an estimated mean of 4.30 and a standard deviation of 0.54 .

Respondents identified uncompetitive pricing of micro-insurance products with an estimated mean of 4.29 and a standard deviation of 0.54 as one key factor that influences the demand of the microinsurance product. The respondents noted that low government support in micro-insurance programs also affects the demand of micro-insurance and this was identified with an estimated mean of 4.18 and a standard deviation of 0.50. Again, respondents agreed to the statement that low-income levels of respondents relegate insurance products to secondary needs with an estimated mean of 4.14 and a standard deviation of 0.59 .

Respondents further identified that religious or cultural factors influence the demand for insurance products with an estimated mean of 4.05 and a standard deviation of 0.59 . Finally, low public trust in micro-insurance was also identified as a factor that influences the demand for micro-insurance. The study identified the lack of innovative micro-insurance product, inadequate distribution channels which limit the reach and low levels of publicity, lack of supportive micro-insurance legal framework, uncompetitive pricing of micro-insurance products, low government support in 
International Journal of Business and Management Review

Vol.8, No.4, pp.39-57, July 2020

Published by ECRTD-UK

Print ISSN: 2052-6393(Print), Online ISSN: 2052-6407(Online)

micro-insurance programs, low-income levels of respondents relegate insurance products to secondary needs, religious or cultural factors influence the demand of insurance products and low public trust as the factors that affect the demand of micro-insurance products (see table 5).

The study found the lack of innovative micro-insurance product, inadequate distribution channels which limit the reach and low levels of publicity, lack of supportive micro-insurance legal framework, Uncompetitive pricing of micro-insurance products, low government support in micro-insurance programs, low-income levels of respondents relegate insurance products to secondary needs, religious or cultural factors influence the demand of insurance products and low public trust as the factors that affect the demand of micro-insurance products.

This affirms the findings of Kamau (2013), Erlbeck (2017) and Odenyo (2013) who concluded in their study that the factors that influence the demand of microinsurance in emerging markets include the lack of innovative micro-insurance product, inadequate distribution channels which limit the reach and low levels of publicity, lack of supportive micro-insurance legal framework, lack of competitive pricing of micro-insurance products, low government support in microinsurance programs, low-income levels of respondents relegate insurance products to secondary needs, religious or cultural factors influence the demand of insurance products and low public trust.

\section{Ways to Increase the Patronage of Micro-insurance}

The third objective seeks to examine ways to increase the patronage of micro-insurance products. The results were presented in Table 6.

Table 6: Ways to increase the patronage of Micro-insurance (Client)

\begin{tabular}{llll}
\hline Variable & $\mathbf{N}$ & $\mathbf{M}$ & SD \\
\hline $\begin{array}{l}\text { Microinsurance companies should be innovative with } \\
\text { the micro-insurance products }\end{array}$ & 150 & 4.15 & 0.42 \\
$\begin{array}{l}\text { Micro-insurance companies should institute measures, } \\
\text { products, and processes that will help to build trust }\end{array}$ & 4.12 & 0.33 \\
$\begin{array}{l}\text { Documentation on micro-insurance policies should be } \\
\text { simplified }\end{array}$ & 450 & 4.02 & 0.18 \\
$\begin{array}{l}\text { There should be efficient service delivery channels to } \\
\text { help market the micro-insurance products }\end{array}$ & 4.00 & 0.20 \\
$\begin{array}{l}\text { There should be donor and government support in } \\
\text { promoting micro-insurance products }\end{array}$ & 150 & 3.93 & 0.18 \\
Total & $\mathbf{1 5 0}$ & $\mathbf{4 . 0 7}$ & $\mathbf{0 . 1 7}$ \\
\hline
\end{tabular}

Source: Field Survey (2018)

From Table 10, the researcher sought to find ways to increase the patronage of micro-insurance. The respondents identified that one of the ways to increase the patronage of micro-insurance is for Micro-insurance companies should be innovative with the Micro-insurance products with an estimated mean of 4.15 and a standard deviation of 0.42 . Also, respondents identified that Micro- 
International Journal of Business and Management Review

Vol.8, No.4, pp.39-57, July 2020

Published by ECRTD-UK

Print ISSN: 2052-6393(Print), Online ISSN: 2052-6407(Online)

insurance companies should institute measures, products, and processes that will help to build trust with an estimated mean of 4.12 and a standard deviation of 0.33 as a way of increasing the patronage of Micro-insurance. The respondents further identified that documentation on Microinsurance policies should be simplified to enhance the demand of Micro-insurance products. This was identified with an estimated mean of 4.02 and a standard deviation of 0.18. Another way identified by respondents as a way of increasing patronage of Micro-insurance is that there should be efficient service delivery channels to help market the micro-insurance products with an estimated mean of 4.00 and a standard of 0.20 . Respondents further identified that one of the ways to increase patronage of Micro-insurance products is that there should be donor and government support in promoting micro-insurance products with a mean of 3.93 and a standard deviation of 0.18 .

The study identified that Microinsurance companies should be innovative with the micro-insurance products; Micro-insurance companies should institute measures, products, and processes that will help to build trust; documentation on micro-insurance policies should be simplified; there should be efficient service delivery channels to help market the micro-insurance products and lastly, there should be a donor and government support in promoting microinsurance products as the ways to increase patronage of micro-insurance products. The study identified that Microinsurance companies should be innovative with the micro-insurance products; Micro-insurance companies should institute measures, products, and processes that will help to build trust; documentation on micro-insurance policies should be simplified; there should be efficient service delivery channels to help market the micro-insurance products and lastly, there should be the donor and government support in promoting microinsurance products as the ways to increase patronage of microinsurance products. This result confirms the findings of Odenyo (2013) and Cole (2015) who found that the development of the innovative product, establishing processes that build trust in clients, instituting efficient service delivery channels, documentation should be simplified and the government should support micro-insurance products.

\section{CONCLUSIONS}

The study concludes that micro-insurance is crucial to improving the social welfare of citizens. The study concludes that microinsurance leads to improving the welfare of the vulnerable in Ghana in that the study identified that Micro-insurance provides financial support to the poor in the event of a disaster; Micro-insurance ensures social protection against disasters and shocks; it encourages savings; it provides employment and as well as enhancing asset accumulation. This affirms the findings of Bauchet, Damon, and Larsen (2017), Boadu et al. (2014), Dietrich (2017), Akotey, and Adjasi (2018) and Odenyo (2013). The study concludes that the lack of innovative micro-insurance product, inadequate distribution channels which limit the reach and low levels of publicity, the lack of supportive micro-insurance legal framework, the lack of competitive pricing of microinsurance products, low government support in micro-insurance programs, the low-income levels of respondents which relegate insurance products to secondary needs, the religious or cultural factors influence the demand of insurance products and the low public trust in micro-insurance products as the factors that affect the demand of micro-insurance products which affirms the 
International Journal of Business and Management Review

Vol.8, No.4, pp.39-57, July 2020

Published by ECRTD-UK

Print ISSN: 2052-6393(Print), Online ISSN: 2052-6407(Online)

findings of Kamau (2013), Erlbeck (2017) and Odenyo (2013). The study concludes that the development of the innovative product, the establishment of processes that build trust in clients, the institution of efficient service delivery channels, the documentation of micro-insurance policies should be simplified and the government's support for micro-insurance products are the ways to increase patronage of micro-insurance products which support the findings of Odenyo (2013) and Cole (2015).

\section{Recommendations of the Study}

Insurance companies should create awareness of the micro-insurance products increase patronage. The government should enforce a legal framework for micro-insurance products. There should also be competitive pricing for micro-insurance products. Insurance companies should reduce the manual procedures involved in accessing micro-insurance products. Insurance companies should provide adequate distribution channels to promote its micro-insurance products. Individuals in society should be educated to know the importance of micro-insurance to avoid them relegating insurance products to secondary needs. Insurance companies should put in place measures to build public trust in micro-insurance.

\section{Limitations and Future Research}

The research recommends that future studies should focus on employing a quantitative research approach or triangulation research approach. Additionally, the researcher recommends that subsequent studies should blend more insurance firms instead of the few selected insurance firm to compare and contrast the findings. More so, the sample size of the study should be increased.

The paper was limited to a single geographic area, therefore the results may not hold in other countries due to cultural differences that may pertain to those countries.

Also, the applicability of these findings to other Sub-Saharan countries needs further investigation. A similar study with the same objectives should be conducted over a relatively wider scope to include other regions of the country.

\section{References}

Agyapong, D. (2010). Micro, small and medium enterprises' activities, income level and poverty reduction in Ghana-A synthesis of related literature. International Journal of Business and Management, 5(12), 196.

Akotey, J. O., \& Adjasi, C. (2014). The impact of micro-insurance on household asset accumulation in Ghana: An asset index approach. The Geneva Papers on Risk and Insurance-Issues and Practice, 39(2), 304-321.

Akotey, J. O., \& Adjasi, C. K. (2018). Microinsurance and Consumption Smoothing Among LowIncome Households in Ghana. The Journal of Developing Areas, 52(4), 151-165.

Akotey, O. J., Osei, K. A., \& Gemegah, A. (2011). The demand for micro insurance in Ghana. The Journal of Risk Finance, 12(3), 182-194.

Arun, T. G., \& Steiner, S. (2008). Micro-insurance in the context of social protection.

Asmare, A., \& Worku, A. (2018). Determinants of Micro-Insurance Demand in Jimma Zone. International Research Journal of Business Studies, 11(3), 145-157. 
International Journal of Business and Management Review

Vol.8, No.4, pp.39-57, July 2020

Published by ECRTD-UK

Print ISSN: 2052-6393(Print), Online ISSN: 2052-6407(Online)

Barik, B. (2012). Customer expectation about insurance product in India life insurance industry. International Journal of Business and Management Tomorrow, 2 (2).

Boadu, F., Dwomo-Fokuo, E., Boakye, J. K., \& Frimpong, A. O. (2014). Employee appraisal and performance in the hospitality industry. Research in Business and Management, 1(2), 146165.

Boateng, G. O., Boateng, A. A., \& Bampoe, H. S. (2015). Microfinance and poverty reduction in Ghana: Evidence from policy beneficiaries. Review of Business \& Finance Studies, 6(1), 99-108.

Braverman, A., \& Guasch, J. L. (1986). Rural credit markets and institutions in developing countries: Lessons for policy analysis from practice and modern theory. World Development, 14(10-11), 1253-1267.

Churchill, C. (2006). Protecting the poor: A Micro insurance Compendium, International labor organization, Geneva.

Cooke, E., Hague, S., \& McKay, A. (2016). The Ghana poverty and inequality report: Using the 6th Ghana living standards survey. New York: UNICEF.

De Bock, O., \& Gelade, W. (2012). The demand for microinsurance: A literature review. ILO Microinsurance Innovation Facility Research Paper, (26).

Dror, D. M., \& Preker, A. S. (2002). Social Re Insurance. A new approach to sustainable community health financing.

Healey, J., \& Killick, T. (2000). Using aid to reduce poverty. Foreign Aid and Development: Lessons Learnt and Directions for the Future, 223-46.

Huppi, M., \& Feder, G. (1990). The role of groups and credit cooperatives in rural lending. The World Bank Research Observer, 5(2), 187-204.

Jones, N., Tafere, Y., \& Woldehanna, T. (2010). Gendered risks, poverty and vulnerability in Ethiopia: To what extent is the Productive Safety Net Programme (PSNP) making a difference. London: Overseas Development Institute.

Kessey, K. D. (2013). Global poverty reduction policy and implementation strategies at local level, integrated planning options and challenges in a developing country, Ghana. Merit Research Journal of Art, Social Science and Humanities (ISSN: 2350 2258) Vol. 1(6) pp. 076-085, October, 2013 Available online http://www. Meritresearch journals.org/assh/index.htm Copyright (C) 2013 Merit Research Journals.

Morduch, J. (2006). Microinsurance: The next revolution. Understanding Poverty, 337-356.

Morsink, K., \& Geurts, P. (2011). Informal trust building factors and the demand for microinsurance. In 7th annual international microinsurance conference, Rio de Janeiro (pp. 8-11).

National Insurance Commission (2013). Annual Report, 2013. [Online] Available: http:// www.nic.gh.org. (May20, 2013)

National Insurance Commission. (2008). Annual Report, 2008. [Online] Available: http:// www.nic.gh.org. (May20, 2013)

National Insurance Commission. (2010). Annual Report, 2010. [Online] Available: http:// www.nic.gh.org. (May 20, 2013).

National Statistical Service (2017). Poverty Survey, 2017. Retrieved from http://www2.statsghana.gov.gh/nada/index.php/home. 
International Journal of Business and Management Review

Vol.8, No.4, pp.39-57, July 2020

Published by ECRTD-UK

Print ISSN: 2052-6393(Print), Online ISSN: 2052-6407(Online)

Obeng, C. K. (2011). The impact of micro-credit on poverty reduction in rural areas: a case study of Jaman North District, Ghana (Doctoral dissertation).

Odenyo, K. O. (2018). Factors Affecting Micro Insurance Penetration in Kenya (Doctoral dissertation, United States International University-Africa).

Satterthwaite, D. \& Bartlett, S. (2017). "Editorial: The full spectrum of risk in urban centres: changing perceptions, changing priorities." Environment and Urbanization 29(1): 3-14.

Sirojudin, \& Midgley, J. (2012). Microinsurance and Social Protection: The Social Welfare Insurance Program for Informal Sector Workers in Indonesia. Journal of Policy Practice, 11(1-2), 121-136.

Tumaini, Y.\& Isaac, K. (2014). "Micro Insurance: A Positive Intervention to Household Income and Poverty Reduction?" Experience from Marangu Tanzania Research Journal of Finance and Accounting www.iiste.orgISSN 2222-1697 (Paper) ISSN 2222-2847 (Online), 5, 24, 2014.

World Bank. (2011a). Access to Financial Services and the Financial Inclusion Agenda Around the World. Washington DC.

World Bank. (2011b). Financial Sector Program Update: Technical Notes. Access to Finance, July 2011. www.bsp.gov.ph. Retrieved from www.myinsuranceclub.com/insurancenews/insurance-penetration-in-asian-countries www.neda.gov.ph.

Yarumba, T., \& Kazungu, I. Micro Insurance: A Positive Intervention to Household Income and Poverty Reduction? Experience from Marangu Tanzania. 